\title{
Chemical and Mineralogical Composition Analysis of Different Nigerian Metakaolins
}

Ike Chimdieze Daniel ${ }^{\mathrm{a}}$, William Ghann ${ }^{\mathrm{b}}$, Igboko Ndubuisi ${ }^{\mathrm{a}}$, Kenneth Okpala ${ }^{\mathrm{a}}$, Birol Ozturk ${ }^{\mathrm{c}}$, Mohammed M. Rahman ${ }^{d}$ Faisal Islam Chowdhurye, Md. Nuruzzaman Khan ${ }^{\mathrm{f}}$, Md. Rezaur Rahman $^{\mathrm{g}}$, Md. Abdul Majed Patwary ${ }^{\mathrm{h}}$, Nafees Ahmed ${ }^{\mathrm{i}}$ and Jamal Uddin ${ }^{\mathrm{b} *}$

${ }^{a}$ Chemical Engineering Department, Federal University of Technology, PMB 1526, Owerri, Nigeria

${ }^{b}$ Center for Nanotechnology, Department of Natural Sciences, Coppin State University, 2500

W. North Ave., Baltimore, MD 21216

${ }^{c}$ Department of Physics and Engineering Physics, Morgan State University, 1700 E. Cold Spring Ln, Baltimore, MD 21251

${ }^{d}$ Chemistry department, King Abdulaziz University, Jeddah 21589, Saudi Arabia

${ }^{e}$ Department of Chemistry, University of Chittagong, Chittagong, Bangladesh

${ }^{f}$ Department of Applied Chemistry and Chemical Engineering, University of Dhaka, Dhaka1000, Bangladesh

${ }^{g}$ Department of Chemical Engineering and Energy Sustainability, Faculty of Engineering, University Malaysia Sarawak

${ }^{h}$ Department of Chemistry, Comilla University, Cumilla-3506, Bangladesh

i Department of Chemistry, Jagannath University, 9-10, Chittaranjan Avenue, Dhaka

\begin{abstract}
In this work, four different metakaolin samples (C01, A6060, B6075, and C12090) were investigated to determine their constituent elements and the relative quantities of the oxide contents associated with each of the elements. Kaolin samples were collected from different sites at Okpella, a village in the Edo state of Nigeria, West Africa. The metakaolin was produced by calcination at $750^{\circ} \mathrm{C}$, which was followed by the dealumination process. The prepared samples were characterized by Field Emission Scanning Electron Microscope (FE-SEM), Energy Dispersive X-ray Spectroscopy (EDS), Fourier Transform Infrared Resonance (FTIR) spectroscopy, and X-ray diffraction (XRD) technique. Digital images were obtained and analyzed to determine the texture and porosity of the samples. FE-SEM images showed a slight difference in the morphology of the samples. Differing percentages of metal oxides were determined from the samples using EDS analysis. The major oxides present in all the samples were Silica (Silicon oxide) and Alumina (Aluminium dioxide). Aluminium was completely absent in C12090 but had a large percentage of silicon (36\%).
\end{abstract}

Keywords: Clay, Kaolin, Oxides, Metakaolin, and Ceramics

\footnotetext{
* Corresponding author.

E-mail address: juddin@coppin.edu

Manuscript History:

Received 2 September, 2021, Revised 15 September, 2021, Accepted 17 September, 2021, Published 31 October, 2021

Copyright (C) 2021 UNIMAS Publisher. This is an open access article under the CC BY-NC-SA 4.0 license.

https://doi.org/10.33736/jaspe.3884.2021

e-ISSN: 2289-7771
} 


\section{Introduction}

Kaolin is a hydrated Aluminum silicate clay having the empirical formula of $\mathrm{Al}_{2} \mathrm{Si}_{2} \mathrm{O}_{5}(\mathrm{OH})_{4}$. Kaolin was first discovered in China in the $7^{\text {th }}$ century and thus it is referred to as China clay. Kaolin particles are usually hexagonal in shape with an average size of $500 \mu \mathrm{m}$. [1]. The diameters of the particles usually range from $50 \mu \mathrm{m}$ to $10,000 \mu \mathrm{m}$ and generally contain silicon, aluminium, oxygen, iron, calcium, magnesium, sodium, potassium, phosphorus, and hydroxyl groups. Specifically, it is known to contain $48 \%$ of silicon dioxide $\left(\mathrm{SiO}_{2}\right), 38 \%$ of aluminium oxide $\left(\mathrm{Al}_{2} \mathrm{O}_{3}\right), 1.72 \%$ of iron oxide $\left(\mathrm{Fe}_{2} \mathrm{O}_{3}\right), 0.79 \%$ of calcium oxide $(\mathrm{CaO}), 0.72 \%$ of magnesium oxide $(\mathrm{MgO})$, and $0.41 \%$ of titanium oxide $\left(\mathrm{TiO}_{2}\right)$. [2-6] These percentages may however vary depending on the types of the clay samples. [7] proposed a crystal structure with tetrahedrally coordinated silicon atoms and octahedrally coordinated aluminium atoms as displayed in Figure 1. [8] carried out density functional theory (DFT) calculations on the crystalline structure of Kaolin and reported that the inner hydroxyl groups were nearly parallel whereas the surface hydroxyl groups were slightly perpendicular.

Kaolin could be mined from different parts of the world including the USA, Brazil, and the UK. Kaolin samples are shown in Figure 2. They were obtained from Okpella, Nigeria. This type of clay consists of mainly Kaolinite and sometimes small amounts of other materials such as quartz, mica, rutile feldspar, and bauxite [9].

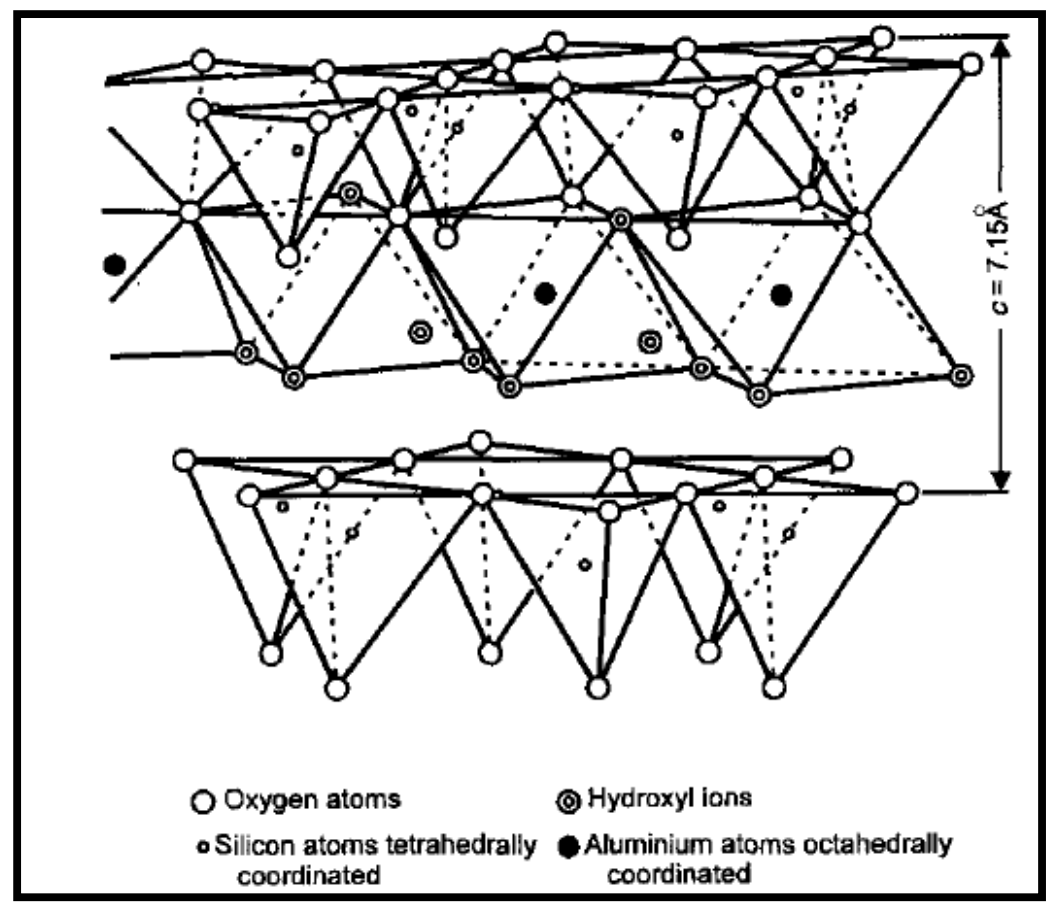

Figure 1. Kaolinite structure, adapted from Murray H. H. (1997) Applied clay mineralogy today and tomorrow, Clay Minerals (1999) 34, 39-49 [10]

Kaolin has a range of properties, making it valuable for several applications, including ceramics, cosmetics, toothpaste, food additives, paints, pharmaceuticals, desiccants, crayons, cement, enamels, DSSC sensors, and nanotechnology [11, 12]. However, the paper industry has the most use for Kaolin as fillers and coating on paper [13]. 
Kaolin is made of fine particles, is non-toxic, inert, and exists in different variations of the white colour [14]. Impurities in Kaolin causes off-white colouring hence, it is purified for certain applications $[8,14,15]$.

One of the many applications of kaolin clay is its use in the production of zeolites. Zeolites are important catalysts often used in the oil industry. Thus, the goal of this study was to purify and characterize Kaolin clay for developing zeolites. For all Kaolin samples, it is very important to determine the exact composition of the oxides present in the samples. Characterization of samples provides a means of categorizing them.

One critical step in the production of zeolites is the formation of metakaolin through the process of calcination. Production of zeolite occurs after calcination, dealumination, and characterization of resulting metakaolin. Metakaolins are very important and have several applications owing to their unique properties such as durability, resistance to chemical attack, diminished permeability and improved strength.

The specific goal of characterization studies carried out in this work was to determine the percentage of the various oxides present in the metakaolin samples. The samples were analyzed using Fourier Transform Infrared (FTIR) spectroscopy, Field Emission Scanning Electron Microscopy (FESEM), Energy Dispersive X-ray Spectroscopy (EDS), and X-ray diffraction (XRD) methods. FE-SEM imaging was carried out to study the morphologies of the samples.

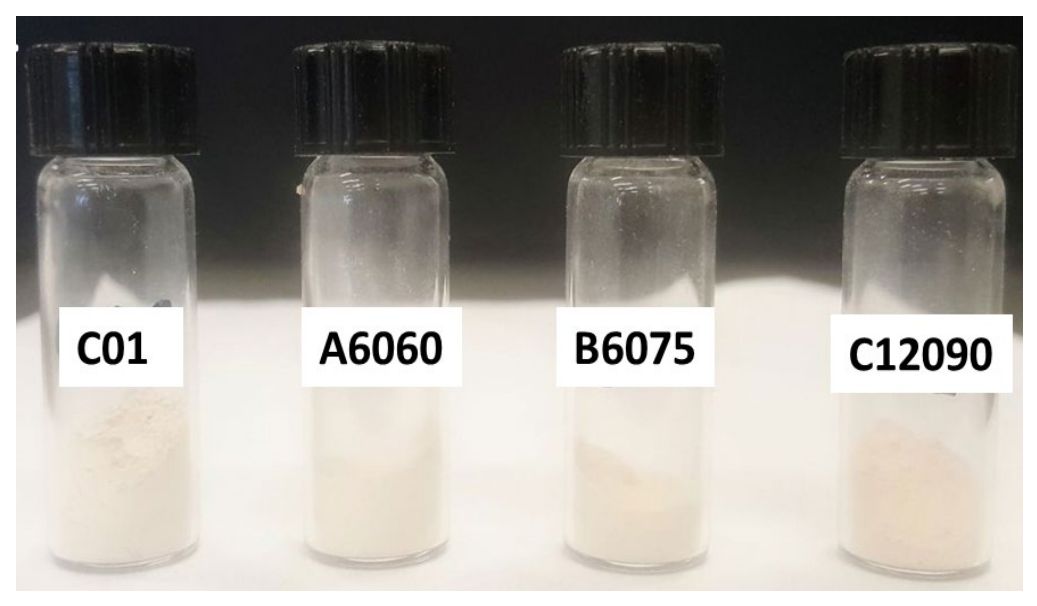

Figure 2. Metakaolin samples (C01, A6060, B6075, and C12090). analyzed in this study obtained from the Okpella mining site.

\section{Experimental Procedure}

\subsection{Kaolin Clay}

The Kaolin clay used in this research work was procured from Okpella village, Edo State Nigeria through the Freedom Group Mining Company. The Kaolin clay was termed as white and offwhite raw Okpella Kaolin due to its mixed white and off-white appearance. The four different samples: C01, A6060, B6075, and C12090 were obtained from four different sites at Okpella village.

\subsection{Size reduction of raw Okpella Kaolin}

The raw materials were ground to reduce their sizes using a custom-made mortar. The reduced samples were sieved using a $75 \mu \mathrm{m}$ sieve before calcination and analysis. 


\subsection{Calcination of Okpella Kaolin}

The ground Kaolin was heated in a muffle furnace from drying state to calcination temperature of $750^{\circ} \mathrm{C}$ at the rate of $10^{\circ} \mathrm{C} / \mathrm{min}$ and was held at this temperature for 15 minutes. Calcination was achieved by evenly placing the fine Kaolin into various crucibles to allow for good heat distribution since the specific heat capacity and latent heat of Kaolin was poor. The obtained metakaolin was placed in a desiccator for cooling prior to dealumination.

\subsection{Dealumination of calcined metakaolin}

The dealumination reaction required an external source of thermal energy to facilitate the dealumination of the metakaolin. About 16.3 grams of the metakaolin was mixed with $10 \mathrm{M}$ of $\mathrm{H}_{2} \mathrm{SO}_{4}$ in a conical flask followed by vigorous stirring to obtain a mixed slurry, which was then left to react in a water bath under manual stirring for 30 minutes at a temperature of $60^{\circ} \mathrm{C}$. This procedure was repeated for all the samples at different reaction times of 60,90, and 120 minutes and temperatures of $75^{\circ} \mathrm{C}$ and $90^{\circ} \mathrm{C}$. At the end of each reaction, the samples were washed with a $10 \mathrm{M}$ aqueous solution of $\mathrm{BaCl}_{2}$. This step was performed to remove all the acid from the samples. Next, the samples were dried at $70^{\circ} \mathrm{C}$ in an oven. Each metakaolin sample was mixed with deionized water in a beaker to form a slurry, which was then poured into a measuring cylinder, serving as the settling tank. The size separation was achieved by allowing free settling of clay suspension in the measuring cylinder. A clay suspension was created from a mixture of clay and deionized water, whereas the settling time of heavier component (quartz) was determined from Stokes' Law equation based on the densities of particles and solvent (water), the viscosity of solvent (water), and the diameter of the particles $(\sim 20 \mu \mathrm{m})$. The settled fine metakaolin clay was dried in the oven for 59 hours at $45^{\circ} \mathrm{C}$ and was packed into sample bottles for the next experimental stage.

\subsection{Characterization techniques}

The morphologies and compositions of all the samples were analyzed with X-ray diffraction (XRD) (Rigaku MiniFlex X-ray diffractometer, Rigaku Analytical Devices, Inc., Wilmington, MA, USA), a Field Emission Scanning Electron Microscopy (FE-SEM) equipped with Energy Dispersive X-Ray Spectroscopy (EDS) (JSM-7100FA JEOL USA, Inc). Attenuated Total Reflectance (ATR) spectra were obtained in the 4000 to $400 \mathrm{~cm}^{-1}$ range with a Thermo Nicolet iS50 FTIR. Digital imaging studies were carried out with a Celestron CMOS Camera from Celestron, Torrance, CA, USA.

\section{Results and Discussion}

\subsection{X-ray diffraction analysis}

Metakaolin samples compositions were characterized by using a Rigaku MiniFlex X-ray diffractometer $(\mathrm{Cu} \mathrm{K} \alpha$ source, $\lambda=0.154185 \mathrm{~nm})$. The X-ray diffraction (XRD) patterns of samples are shown in Figure 3. The high-intensity broad peak centred around $22^{\circ}$ in all the XRD spectra, indicating the abundance of the amorphous $\mathrm{SiO}_{2}$ phase in all samples. Major peaks of the $\mathrm{C} 01$ sample were observed at $2 \theta=12.4^{\circ}, 20.44^{\circ}, 25.0^{\circ}, 38.52^{\circ}$, and $62.36^{\circ}$ corresponding to the (001), (110), $(002),(202)$, and $(060)$ reflections of the kaolinite minerals in the metakaolin samples, respectively $[16,17]$. All the observed major peaks of $\mathrm{C} 01$ were in good agreement with the reported values for the kaolinite minerals in metakaolin $\left(\mathrm{Al}_{2} \mathrm{SiO}_{5}\right)$ and the sharp peaks showed crystallinity. Additionally, XRD patterns of the samples A6060 and B6075 had both major peaks at $2 \theta=25.0^{\circ}$ and $68.4^{\circ}$ corresponding to the (002) and (302) reflections of kaolinite minerals in metakaolin [18]. A6060

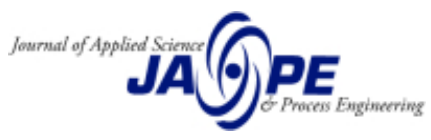


sample had another major peak at $2 \theta=40.25^{\circ}$, corresponding to $(\overline{1} \overline{3} 2)$ reflection of kaolinite minerals in metakaolin. The other two major peaks of the B6075 sample were located at $2 \theta=48.2^{\circ}$ and $60.25^{\circ}$, which were associated with the (141) and (203) reflections of kaolinite minerals in metakaolin, respectively [17,18]. The sample C12090 displayed distinctive three major peaks at $2 \theta=20.8^{\circ}, 42.7^{\circ}$ and $53.38^{\circ}$ corresponding to (110), (041) and (22) reflections of kaolinite minerals in metakaolin, along with smaller intensity diffraction peaks of the kaolinite minerals in metakaolin. [17,18]. The XRD analysis results indicated that all the metakaolin samples were mainly composed of crystallized kaolinite minerals and amorphous $\mathrm{SiO}_{2}$.
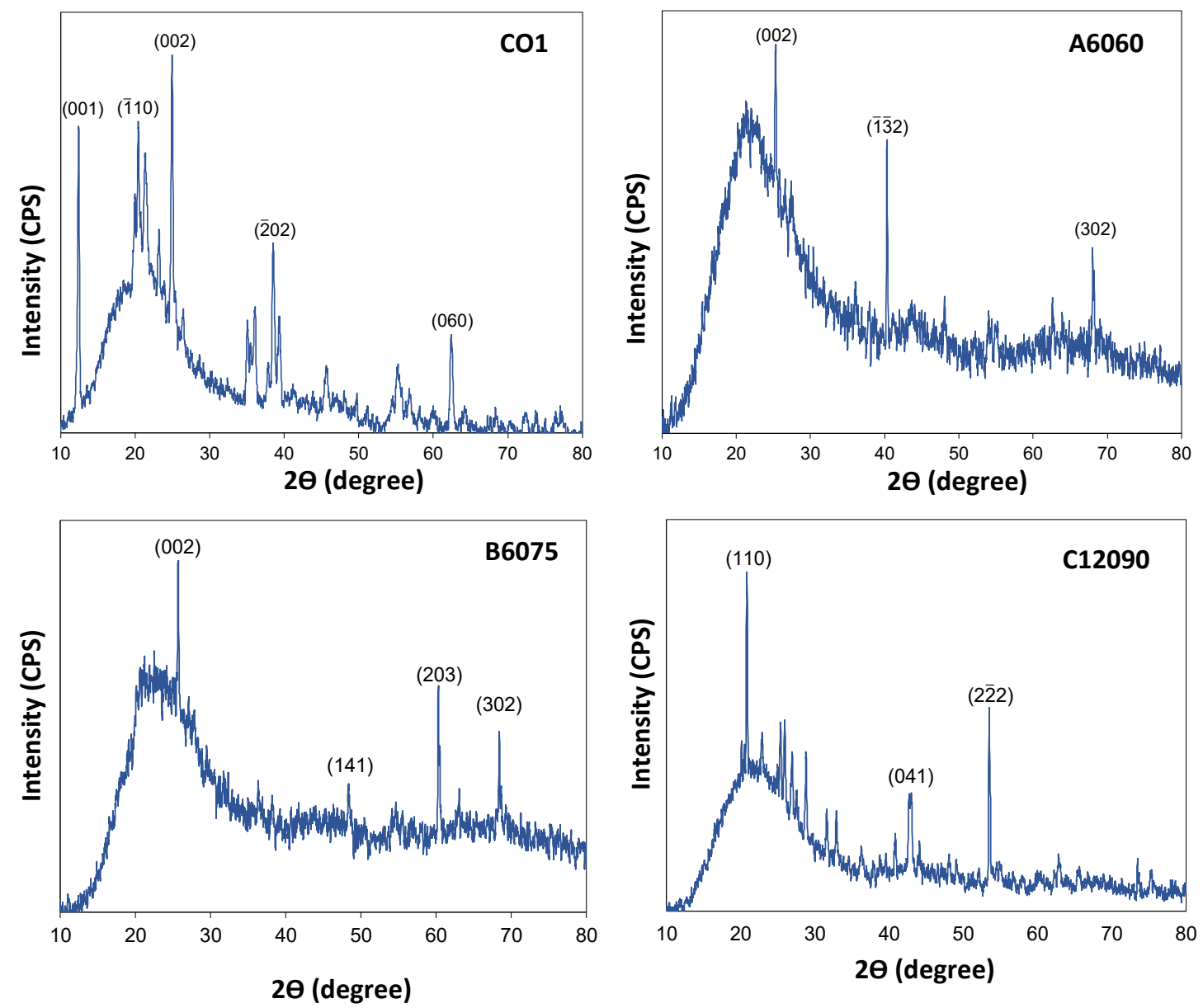

Figure 3. X-ray diffraction analysis of metakaolin samples.

\subsection{Field Emission Scanning Electron Microscopy}

The samples were also examined under the field emission scanning electron microscope (FESEM) to observe the differences in the microstructure at high magnification of the different metakaolin samples. FE-SEM imaging was an important tool for the understanding of the orientation and arrangement of the particles that were present in the metakaolin samples. [19,20] Figure 4 displays the FE-SEM images of the metakaolin C01, A6060, B6075, and C12090 samples at different magnification. 

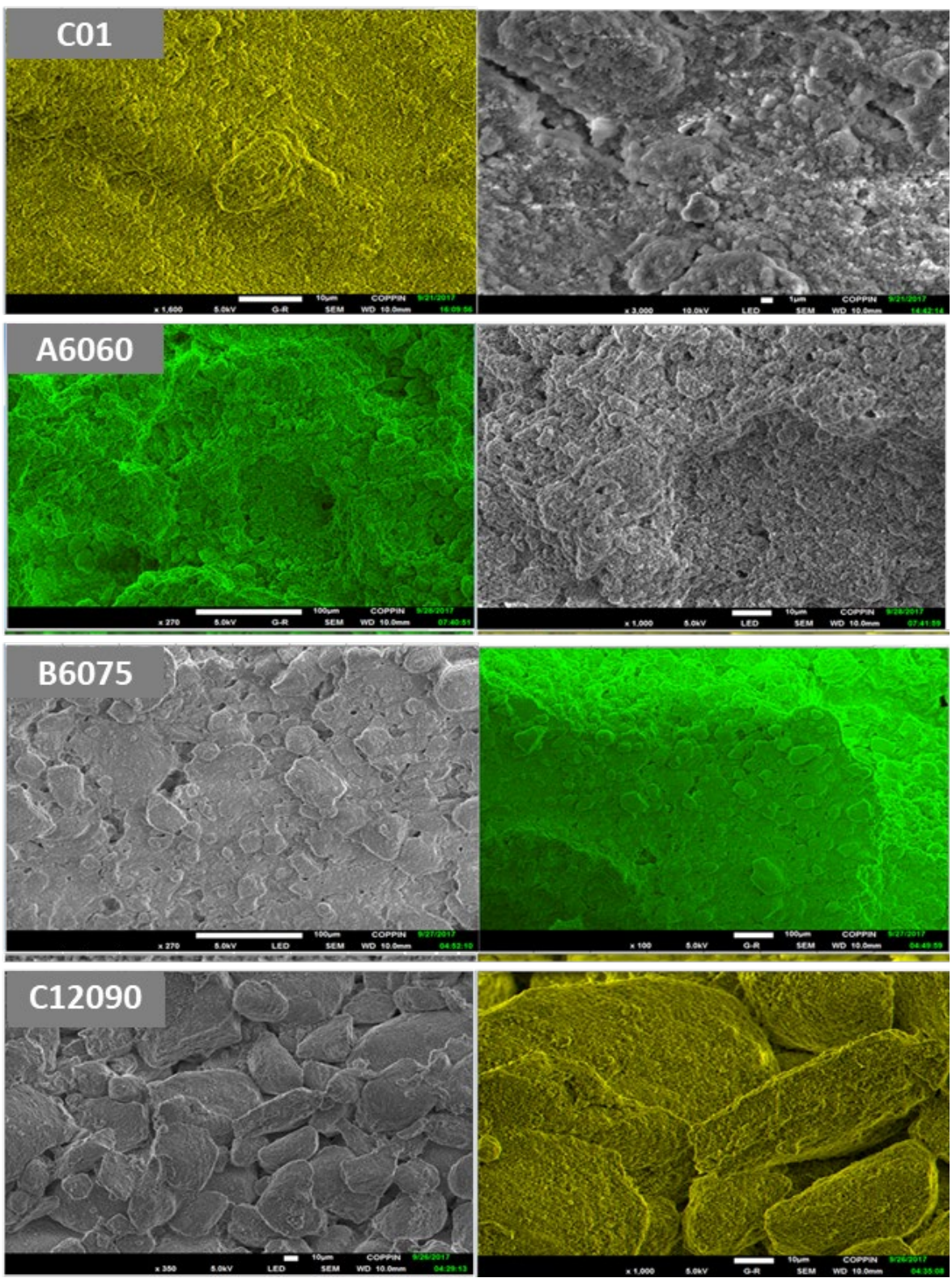

Figure 4. FE-SEM images of metakaolin C01, A6060, B6075, and C12090 samples taken at different magnifications showing their morphologies.

Metakaolin A12090 had distinct structures with clearly defined large grains in agreement with the digital imaging results. Metakaolin B6075 closely resembled A12090 except that the grains were more coagulated. Metakaolin $\mathrm{C} 01$ and A6060 showed similarities in their grain structures and appeared to have more spores compared to the other metakaolin samples.

\subsection{Energy Dispersive X-ray Spectroscopy}

The compositions of metakaolin samples were characterized with Energy Dispersive X-ray Spectroscopy (EDS) studies as shown in Figure 5. The four samples had varying amounts of aluminium oxide and silicon oxide. While there were equal amounts of alumina and silica in B6075, 
C01 and A6060, alumina was almost absent in C12090, which agreed with the X-ray diffraction (XRD) results as explained above. The oxygen peak in relation to the metal was constant for all four samples. Aside from oxygen, silicon, and aluminium, there was no prominent peak representing other metals. In C01, it was observed that the peak for aluminium was slightly higher than that of silicon as was in the case of A6060. The silicon peak in spectra B6075 was however slightly higher than that of aluminium.

The ratio of the atomic concentrations of the elements of the four different samples was determined from the EDS spectra. The ratios for sample $\mathrm{C} 01$ were $\mathrm{Si} / \mathrm{Al}=0.82, \mathrm{Si} / \mathrm{O}=0.23$, and $\mathrm{Al} / \mathrm{O}=0.28$ and the ratios for sample $\mathrm{A} 6060$ were $\mathrm{Si} / \mathrm{Al}=0.93, \mathrm{Si} / \mathrm{O}=0.35$, and $\mathrm{Al} / \mathrm{O}=0.37$. The ratios of the atomic concentrations of the $\mathrm{C} 12090$ sample were markedly different since the Aluminum ratio was relatively low compared to other samples, as indicated by the low intensity of the Aluminum peak in the EDS analysis. The relevant ratio for Silicon and Oxygen was determined as $\mathrm{Si} / \mathrm{O}=0.59$. For all the samples, the main elements present by percentage mass were Oxygen, Silicon, and Aluminum.

These results were consistent with the typical elemental content of kaolin clays [21-23]. EDS and FTIR analysis indicated that the samples were mainly composed of silica and alumina with trace amounts of titanium, potassium, and sodium. Oxides of interest included $\mathrm{SiO}_{2}, \mathrm{Al}_{2} \mathrm{O}_{3}, \mathrm{Fe}_{2} \mathrm{O}_{3}, \mathrm{CaO}$, $\mathrm{TiO}_{2}$, and $\mathrm{K}_{2} \mathrm{O}$-as indicated by the peaks in EDS/FTIR scans.

\subsection{Oxide contents of the metakaolin samples}

The elemental analysis of metakaolin samples is given in Table 1. C01 metakaolin sample had mostly only oxides of Aluminum and Silicon with a very small percentage of Titanium. The average percentages by mass of this sample based on 10 measurements were $18.4 \%$ for Aluminum, $15.1 \%$ for Silicon, and $0.96 \%$ Titanium. These percentages were obtained through quantitative analysis via the Energy-dispersive X-ray spectroscopy.

Table 1. Percentage of Elemental composition of major elements present in metakaolin Samples.

\begin{tabular}{lcccc}
\hline Element & $\underline{\text { C01 }}$ & $\underline{\mathrm{A6060}}$ & $\underline{\mathrm{B6075}}$ & $\underline{\mathrm{C12090}}$ \\
\hline Oxygen & 65.99 & 56.59 & 57 & 61 \\
\hline Aluminum & 18.43 & 21.22 & 19 & - \\
\hline Silicon & 15.11 & 19.84 & 24 & 36
\end{tabular}

Thus, the ratio of aluminium to silicon in metakaolin C01 was 1.2:1. For sample A6060, the average percentages by mass, based on 10 measurements, were $21.2 \%$ for Aluminum and $19.8 \%$ for Silicon, whereas the ratio of Aluminum to Silicon was derived as 1.1:1. B6075 metakaolin sample was mostly composed of oxides of Aluminum and Silicon with a small percentage of Sulphur (not displayed). The percentage by mass of the oxygen was $57 \%$ whereas aluminum and silicon were $19 \%$ and $24 \%$, respectively. A12090 metakaolin sample was distinctly different from all the other metakaolin samples and had mostly silicon without any aluminium, showing that the sample was mainly composed of silicon oxide. 


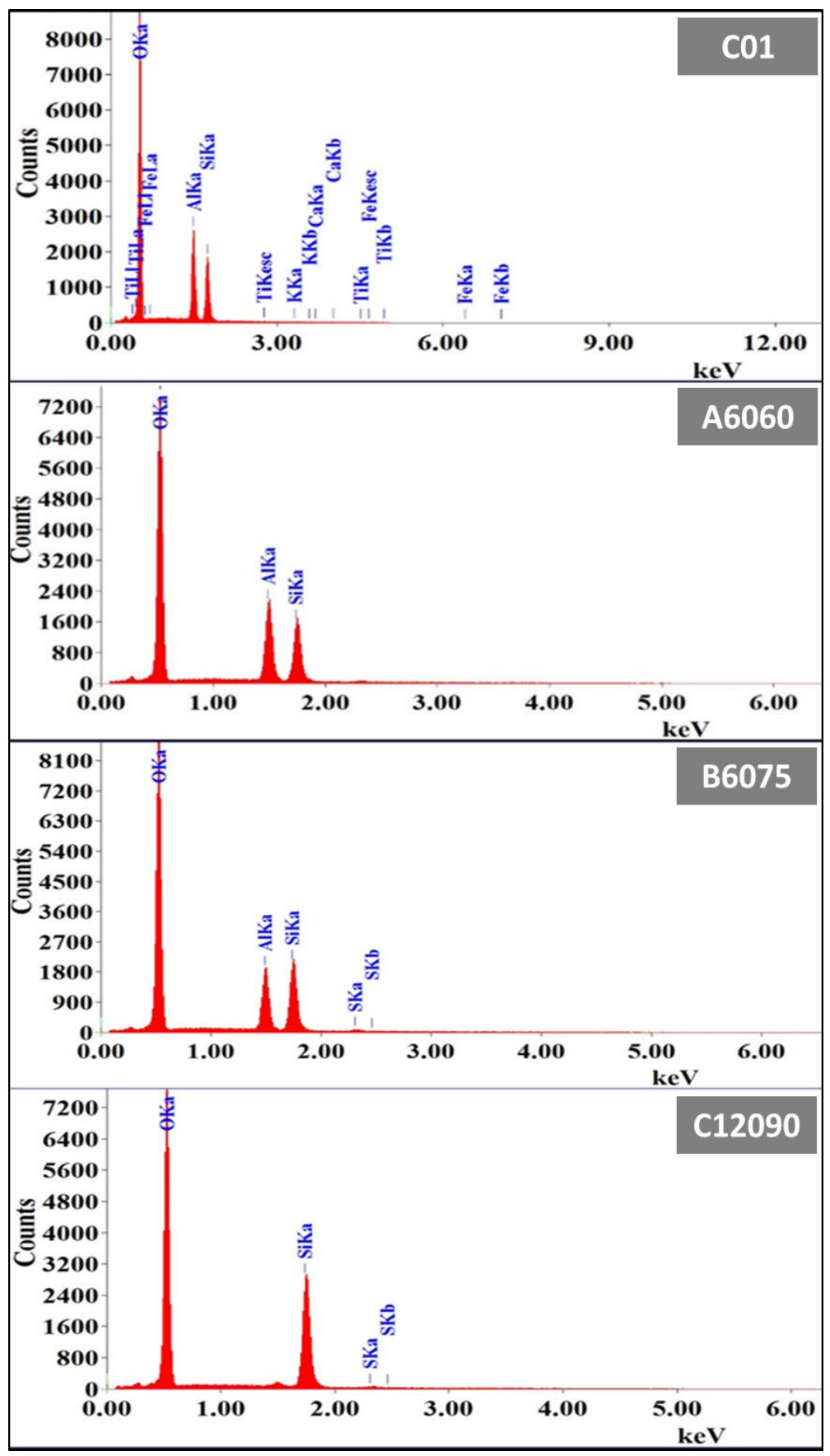

Figure 5. Energy Dispersive X-ray Spectroscopy (EDS) spectra of metakaolin C01, A6060, B6075, and C12090 samples.

\subsection{ATR- FTIR spectroscopy}

FTIR is one of the principal techniques used in the characterization of metakaolin and other types of clay. It is however not suitable for the quantitative determination of the components of metakaolin. Several absorbing bands associated with the FTIR of metakaolin have been reported in 
the literature, where the main characteristic bands that had been generally reported included 3695 , $3660,3625,1035,1020$, and $915 \mathrm{~cm}^{-1}[6,24-27]$.

These peaks accounted for the -OH stretching, Si-O-Si, Si-O-Al and Al-OH bonds present in metakaolin. Figure 6 shows the FTIR spectra of the four different metakaolin samples investigated in this study. In these spectra, the bands between $3600 \mathrm{~cm}^{-1}$ and $3800 \mathrm{~cm}^{-1}$ denoted the $-\mathrm{OH}$ stretching band. The frequencies of $-\mathrm{OH}$ vibrations provided information on the identity of the cation linked with the hydroxyl groups in the sample. The absorbance band around $3600 \mathrm{~cm}^{-1}$, displayed by metakaolin $\mathrm{C} 01$, and $\mathrm{B} 6 \mathrm{O} 75$ samples, was indicative of a larger percentage of aluminium in the samples. The $\mathrm{OH}$ stretching and crystalline hydroxyl were also present in the same region. A broad absorption band around $1038 \mathrm{~cm}^{-1}$ was indicative of the presence of silicon dioxide, accounting for Si-O stretching in clay materials [27-34].
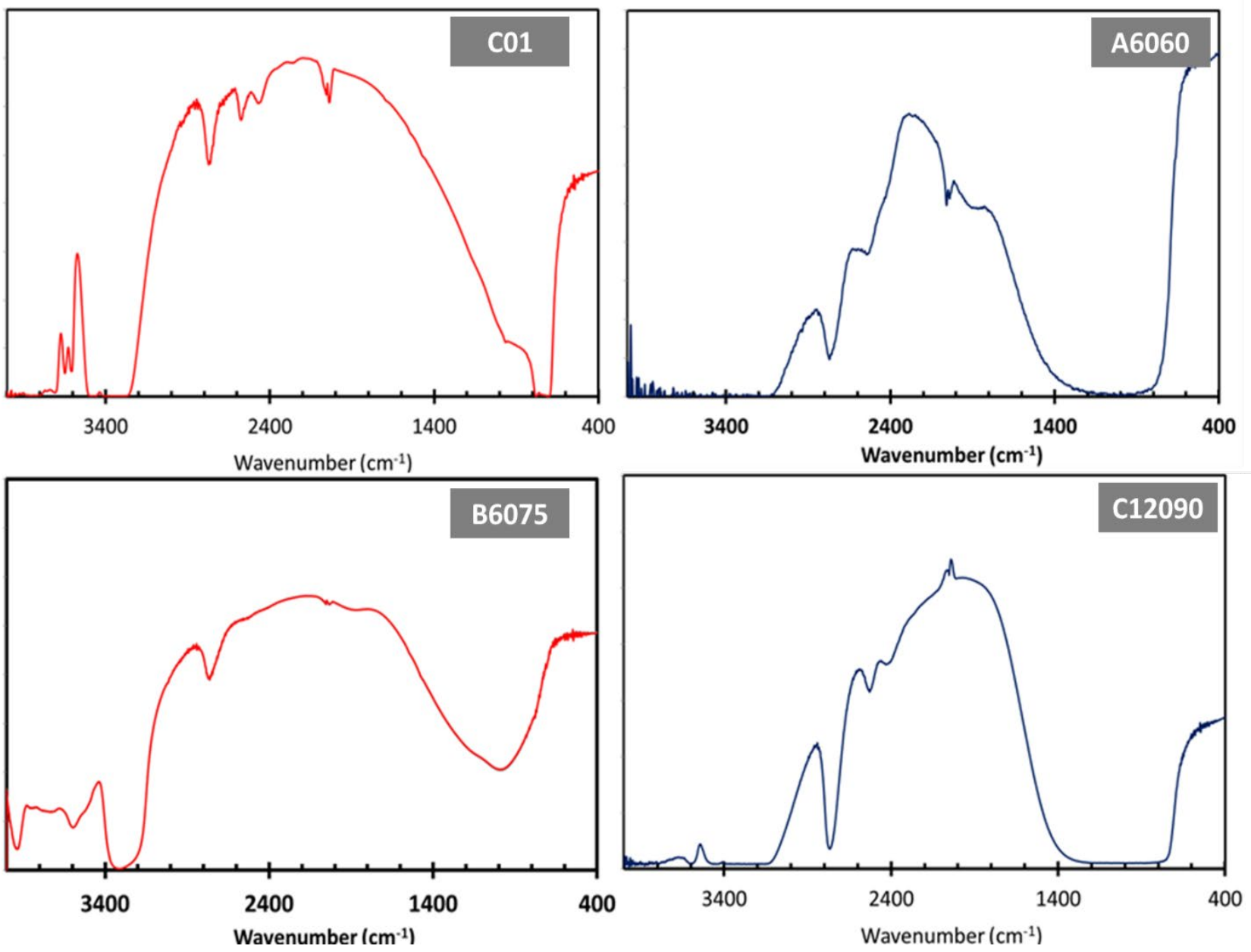

Figure 6. Fourier transform infrared (ATR-FTIR) spectra of four (C01, A6060, B6075, and C12090) different metakaolin samples.

\subsection{Digital Imaging Studies}

Digital images of the samples were captured to compare the physical appearance, morphology and porosity of the samples. As shown in the digital images in Figure 7, all the samples displayed offwhite colour and similar morphology. Metakaolin is white in colour when it is pure. Therefore, the off-white colour was indicative of the presence of impurities in the samples. The particles were seen as 
irregularly shaped and of different sizes. The C01 sample was very grainy compared to the other samples and C12090 showed their morphology. Some coagulation at various points was observed in the metakaolin samples. B6075 and A6060 seemed to have the same kind of texture. The grains of A12090 were coarser compared to other samples.
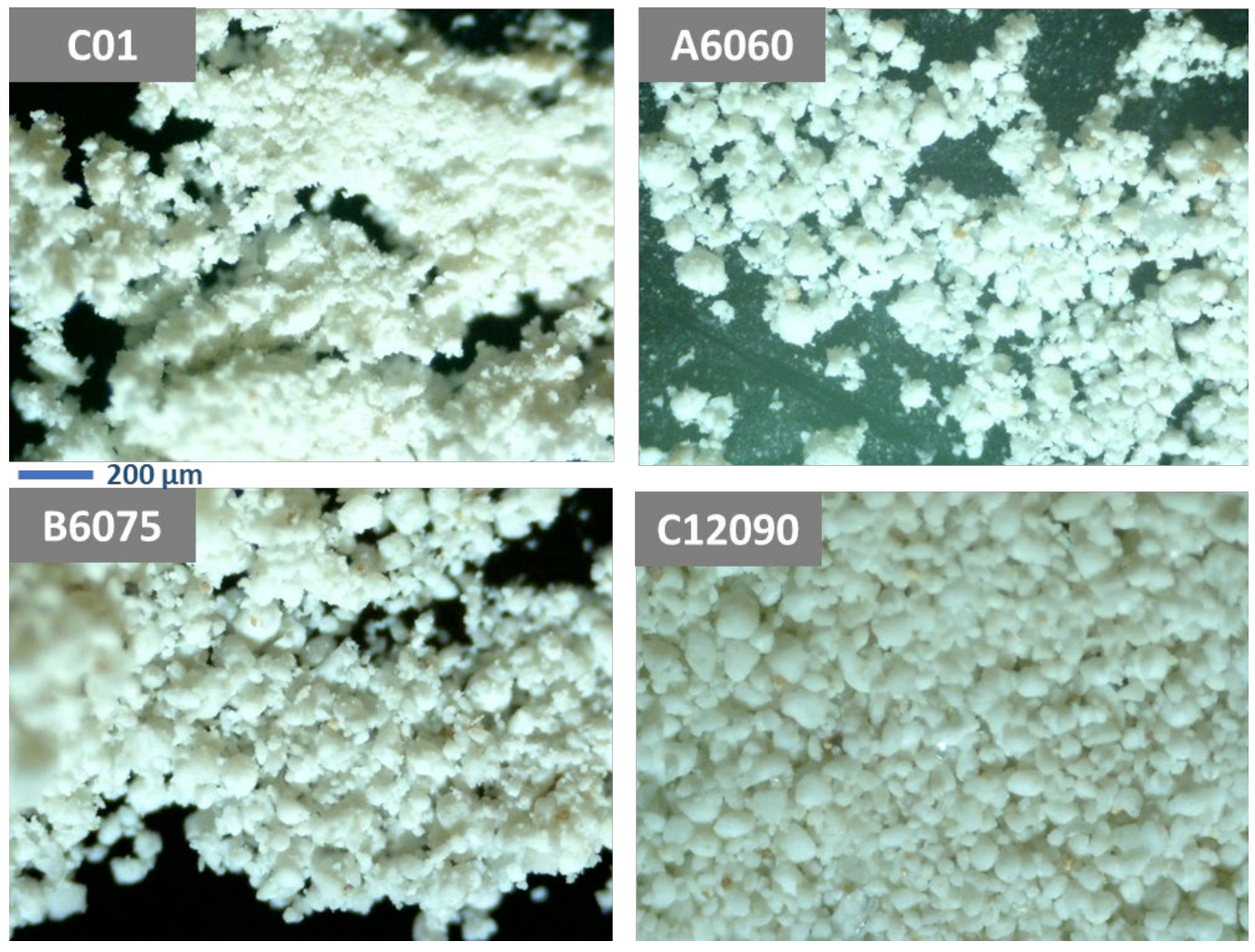

Figure 7. Digital images of the metakaolin samples (C01, A6060, B6075, and C12090).

\section{Conclusions}

The present study dealt with the preparation and characterization of metakaolin for application in various fields of study. Metakaolin is a very important clay that is used in a myriad of applications including ceramics/or catalysts. The relative composition of the metal oxides is crucial as it is used in the determination of the application for a metakaolin sample. In this study, four metakaolin samples were prepared and analyzed in comparative studies of the content of the oxide of the metals present in the samples. The samples were obtained from Okepella, Nigeria in West Africa. Calcination by thermal treatment was carried out at $750^{\circ} \mathrm{C}$ followed by the dealumination process to reduce the Alumina content. The composition of four different metakaolin samples, namely C01, A6060, B6075 and C12090, were compared. The porosity and morphology of the metakaolin samples were also studied. Characterization carried out included X-Ray diffraction, Field Emission Scanning Electron Microscope, Energy Dispersive X-ray Spectroscopy, Fourier Transform Infrared Spectroscopy, and Digital Imaging. It was clear from the Energy Dispersive X-ray analysis that most of the oxides contained Silicon and Aluminium as the main components. Thus, the metakaolin samples were primarily composed of Silica and Alumina. Trace amounts of titanium, potassium and sodium were also observed in the samples studied. While three samples (C01, A6060, B6075) had an almost equal 
amount of silica and alumina, metakaolin C12090 was composed of mainly Silica with only trace amounts of other elements and without the presence of Alumina. The sample C01 contained the highest amount of Aluminium (21.22\%) with C12090 containing no Aluminium. On the other hand, C12090 contained the highest amount of silicon (36\%).

\section{Acknowledgements}

This work was financially supported by the University of Maryland System Wilson E. Elkins Professorship (2485897), Constellation, an Exelon Company, E2- Energy to Educate grant program (163893), and Dept. of Education, SAFRA Title III Grant (2486005). The authors are also grateful to the Institution of Advancement, Coppin State University, for administrative help.

\section{References}

[1] González, J. A., Carreras, A. C., \& Ruiz, M. D. C. (2007). Phase transformations in clays and kaolins produced by thermal treatment in chlorine and air atmospheres. Latin American Applied Research, 37(2), 133-139.

[2] Barrer, R. M., Baynham, J. W., Bultitude, F. W., \& Meier, W. M. (1959). 36. Hydrothermal chemistry of the silicates. Part VIII. Low-temperature crystal growth of aluminosilicates, and of some gallium and germanium analogues. Journal of the Chemical Society (Resumed), 195-208.

[3] Kirk, R. E.; Othmer, D. F. (1991) Encyclopedia of Chemical Technology, 4th ed.; John Wiley \& Sons: New York.

[4] De Lucas, A., Uguina, M. A., Covian, I., \& Rodriguez, L. (1992). Synthesis of 13X zeolite from calcined kaolins and sodium silicate for use in detergents. Industrial \& engineering chemistry research, 31(9), 2134-2140. https://doi.org/10.1021/ie00009a010

[5] Chandrasekhar, S., \& Pramada, P. N. (2001). Sintering behaviour of calcium exchanged low silica zeolites synthesized from kaolin. Ceramics International,27(1), 105-114. https://doi.org/10.1016/S02728842(00)00049-3

[6] Colina, F. G., Esplugas, S., \& Costa, J. (2002). A new extraction procedure for simultaneous quantitative determination of water-soluble metals in reaction products of clays and inorganic salts. Clays and clay minerals, 50(3), 401-405. https://doi.org/10.1346/000986002760833774

[7] Murray, H. H. (2007). Applied clay mineralogy: occurrences, processing and applications of kaolins, bentonites, palygorskitesepiolite, and common clays. Elsevier. ISSN: 1572-4352

[8] White, C. E., Provis, J. L., Riley, D. P., Kearley, G. J., \& Van Deventer, J. S. (2009). What is the structure of kaolinite? Reconciling theory and experiment. The Journal of Physical Chemistry B, 113(19), 67566765. DOI: $10.1021 /$ jp810448t

[9] Olaremu, A. G. (2015). Physico-chemical characterization of Akoko mined kaolin clay. Journal of Minerals and Materials characterization and Engineering, 3(05), 353-361. http://dx.doi.org/10.4236/jmmce.2015.35038

[10] Murray, H. H. (1999). Applied clay mineralogy today and tomorrow. Clay minerals, 34(1), 39-49. https://doi.org/10.1180/000985599546055

[11] Zhang, R., Alecrim, V., Hummelgård, M., Andres, B., Forsberg, S., Andersson, M., \& Olin, H. (2015). Thermally reduced kaolin-graphene oxide nanocomposites for gas sensing. Scientific reports, 5(1), 1-6. DOI: $10.1038 /$ srep07676

[12] Zhang, K., Cui, Z., Xing, G., Feng, Y., \& Meng, S. (2016). Improved performance of dye-sensitized solar cells based on modified kaolin/PVDF-HFP composite gel electrolytes. RSC advances, 6(102), 100079100089. DOI: $\underline{10.1039 / C 6 R A 19803 A}$

[13] Murray, H. H., Harvey, C., \& Smith, J. M. (1977). Mineralogy and geology of the Maungaparerua halloysite deposit in New Zealand. Clays and clay minerals, 25(1), 1-5. https://doi.org/10.1346/CCMN.1977.0250101

[14] Badmus, B. S., \& Olatinsu, O. B. (2009). Geophysical evaluation and chemical analysis of kaolin clay deposit of Lakiri village, southwestern Nigeria. International Journal of Physical Sciences, 4(10), 592-606. https://doi.org/10.5897/IJPS.9000276

[15] Chandrasekhar, S., \& Pramada, P. N. (1999). Investigation on the synthesis of zeolite NaX from Kerala kaolin. Journal of Porous Materials, 6(4), 283-297. https://doi.org/10.1023/A:1009632606671 
[16] Goodyear, J., \& Duffin, W. J. (1961). An X-ray examination of an exceptionally well crystallized kaolinite. Mineralogical magazine and journal of the Mineralogical Society,32(254), 902-907. https://doi.org/10.1180/minmag.1961.032.254.05

[17] Gruner, J. W. (1932). The crystal structure of kaolinite. Zeitschrift für Kristallographie-Crystalline Materials, 83(1-6), 75-88. https://doi.org/10.1524/zkri.1932.83.1.75

[18] Brindley, G. W., \& Robinson, K. (1946). The structure of kaolinite. Mineralogical magazine and journal of the Mineralogical Society, 27(194), 242-253. https://doi.org/10.1180/minmag.1946.027.194.04

[19] Sengupta, P., Saikia, P. C., \& Borthakur, P. C. (2008). SEM-EDX characterization of an iron-rich kaolinite clay. IJEMS, 15, 812-818. ISSN: 0022-4456

[20] Hassan, U. J., \& Abdu, S. G. (2014). Structural analysis and surface morphology of kaolin. Sci. World J., 9(3), 33-37.

[21] Środoń, J., Drits, V. A., McCarty, D. K., Hsieh, J. C., \& Eberl, D. D. (2001). Quantitative X-ray diffraction analysis of clay-bearing rocks from random preparations. Clays and Clay Minerals, 49(6), 514-528. https://doi.org/10.1346/CCMN.2001.0490604

[22] Goldstein, J. I., Newbury, D. E., Michael, J. R., Ritchie, N. W., Scott, J. H. J., \& Joy, D. C. (2017). Scanning electron microscopy and X-ray microanalysis. Springer. https://doi.org/10.1007/978-14939-6676-9

[23] Lim, A. J. M. S., Syazwani, R. N., \& Wijeyesekera, D. C. (2016, July). Impact of oriented clay particles on X-ray spectroscopy analysis. In IOP Conference Series: Materials Science and Engineering, 136 (1), 012012. IOP Publishing. doi:10.1088/issn.1757-899X

[24] Farmer, V.C. (1974) The Infrared Spectra of Minerals. Mineralogical Society Monograph, London. http://dx.doi.org/10.1180/mono-4

[25] Gardsden, J.A. (1975) Infrared Spectra of Minerals and Related Inorganic Compounds. Butterworth \& Co Publishers, Ltd., London. ISBN 0-408-70665-1.

[26] Saikia, B. J., \& Parthasarathy, G. (2010). Fourier transform infrared spectroscopic characterization of kaolinite from Assam and Meghalaya, Northeastern India.J. Mod. Phys, 1(4), 206-210. doi: 10.4236/jmp.2010.14031.

[27] Caponi, N., Collazzo, G. C., Jahn, S. L., Dotto, G. L., Mazutti, M. A., \& Foletto, E. L. (2017). Use of Brazilian kaolin as a potential low-cost adsorbent for the removal of malachite green from colored effluents. Materials Research, 20, 14-22. https://doi.org/10.1590/1980-5373-MR-2016-0673

[28] Costa, E., De Lucas, A., Uguina, M. A., \& Ruiz, J. C. (1988). Synthesis of 4A zeolite from calcined kaolins for use in detergents. Industrial \& engineering chemistry research,27(7), 1291-1296. https://doi.org/10.1021/ie00079a033

[29] Benco, L., Tunega, D., Hafner, J., \& Lischka, H. (2001). Ab initio density functional theory applied to the structure and proton dynamics of clays. Chemical Physics Letters, 333(6), 479-484. https://doi.org/10.1016/S0009-2614(00)01412-3

[30] Nayak, P. S., \& Singh, B. K. (2007). Instrumental characterization of clay by XRF, XRD and FTIR. Bulletin of Materials Science, 30(3), 235-238.

[31] Parthasarathy, G., Kunwar, A. C., \& Srinivasan, R. (2001). Occurrence of moganite-rich chalcedony in Deccan flood basalts, Killari, Maharashtra, India. European Journal of Mineralogy, 13(1), 127-134. https://doi.org/10.1127/0935-1221/01/0013-0127

[32] Babel, S., \& Kurniawan, T. A. (2003). Low-cost adsorbents for heavy metals uptake from contaminated water: a review. Journal of hazardous materials, 97(1-3), 219-243. https://doi.org/10.1016/S03043894(02)00263-7

[33] Scorzelli, R. B., Bertolino, L. C., Luz, A. B., Duttine, M., Silva, F. A. N. G., \& Munayco, P. (2008). Spectroscopic studies of kaolin from different Brazilian regions. Clay Minerals, 43(1), 129-135. http://dx.doi.org/10.1180/claymin.2008.043.1.10

[34] Panda, A. K., Mishra, B. G., Mishra, D. K., \& Singh, R. K. (2010). Effect of sulphuric acid treatment on the physico-chemical characteristics of kaolin clay. Colloids and Surfaces A: Physicochemical and Engineering Aspects, 363(1-3), 98-104. http://dx.doi.org/10.1016/j.colsurfa.2010.04.022 